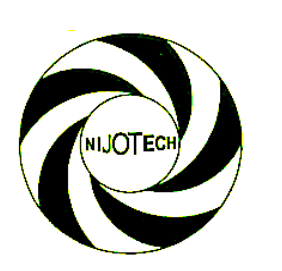

Nigerian Journal of Technology (NIJOTECH)

Vol. 38, No. 3, July 2019, pp. 702 - 706

Copyright@ Faculty of Engineering, University of Nigeria, Nsukka,

Print ISSN: 0331-8443, Electronic ISSN: 2467-8821 www.nijotech.com

http://dx.doi.org/10.4314/njt.v38i3.23

\title{
COOLING EFFECTS ON PHOTOVOLTAIC MODULE PERFORMANCE IN THE TROPICAL REGION
}

\author{
T. O. Ale ${ }^{1}$ and K. J. Rotipin ${ }^{2, *}$ \\ 1, Dept of Elec. and Elec. Engr'G, Federal Univ. Of TeCH., P.M.B. 704 Akure, Ondo State, NIGeria \\ 2. DePARTMENT OF MEChANICAL ENGINEERING, UniVERSITY OF IBADAN, IBADAN, OYo STATE, NIGERIA \\ E-mail addresses; ${ }^{1}$ toale@futa.edu.ng ${ }^{2}$ rotinkay98@yahoo.com
}

\begin{abstract}
This research was carried out to investigate the effects of cooling on Photovoltaic (PV) module performance in a tropical region. A Photovoltaic module system was set up in an outdoor environment to expose it to real life operating conditions at the Quadrangle, Faculty of Technology, University of Ibadan, Oyo State, Nigeria (7024'7.0632' ' $N$, $3^{\circ} 55^{\prime} 2.3268^{\prime \prime}$ ), where all the measuring devices were connected to extract all data that determine the power generated by the PV. The experiment was repeated under water cooling condition. Time series analysis was performed on the data collected from the experimental set up. The results indicated that under water cooling condition, the temperature decreased maximally by $24.1^{\circ} \mathrm{C}$. This leads to a percentage increase of $10.06 \%$ of the open circuit voltage, the maximum power delivered by the PV module also increases by $9.83 \%$ and this effectively increases the conversion efficiency of the PV module by $9.83 \%$. The cooling arrangement maintains the temperature to a certain limit, between $30.6^{\circ} \mathrm{C}$ and $34.5^{\circ} \mathrm{Cthereby}$ avoiding long term thermal degradation. The result of this work further corroborated the results of works done from the temperate region.
\end{abstract}

Keywords: Conversion Efficiency, Performance, Photovoltaic Module, Thermal Degradation.

\section{INTRODUCTION}

Solar energy, as a renewable energy source, is obtained by collecting the energy that the sun gives off as radiation. Solar energy has become a focus for many researchers in recent years; this is because of its numerous advantages over conventional sources of energy. There are two major solar technologies; which include thermal and photovoltaic technologies [1]. A solar photovoltaic (PV) technology is one of the most significant and rapidly developing renewableenergy technologies, and its potential future uses are notable [2].

The conversion of solar energy to electrical energy occurs by Photovoltaic modules. Solar Photovoltaic module is a collection of Photovoltaic cells [3]. A photovoltaic cell is a semiconductor device that generates direct current (DC) electricity when sunlight falls on it [4]. The first PV cells were produced by Bell Laboratories in 1954 [5] and since then the technology has been improving, resulting in growth in the efficiency and reduction of costs.

One of the most challenging factors in using photovoltaic systems is that the conversion efficiency of PV modules is still relatively low, about $15 \%$ [6]. In Laboratories, efficiencies of up to $25 \%$ have been reached, but in commercial use the efficiencies reach only $14-17 \%$ [5].

This efficiency decreases further during the operational period by many factors. Some of the factors influencing optimal performance of PV cells are dust properties, wind velocity, glazing characteristics, site characteristics, ambient temperature, humidity, system tilt angle and module temperature. One of these factors is proposed for consideration in this work.

Literatures revealed that the aforementioned factors affect the performance of PV modules. The PV module temperature according to ([6-9]) has major

* Corresponding author, tel: + 234-803-368-1227 
effects on the power output of the Module. The researchers then proposed cooling methods that will enhance the performance of module in their region (Temperate region). The results showed that there is significant increase in efficiency after cooling of the PV module.

Some of the reviews of work done in the tropical region $([3,10-14])$ showed the effect of climatic and environmental factors (such as ambient temperature, dirt and dust properties, shading, and acidic rain) on the performance of the PV module.

Nazar [15] did a review on different methods of efficiency improvement of solar panel. Solar tracking, Dust cleaning and cooling technique are the methods emphasized.

From the above literatures, it was observed that the thermal response of the PV module is the major factor that affects the electrical power output. The PV module receives the incident irradiation; a portion of it is converted to electricity in proportional with the module efficiency. The rest of the incident irradiation heat up the PV module and thereby increases its operating temperature in relation to the PV material heat capacity [16].

It was ascertained by most authors from the temperate region that temperature of the PV module, among other factors, has major effect on its performance. In this work, the effects of cooling on the optimal performance of photovoltaic module in the tropical region were established experimentally. The rest of the paper is organized as follows: the experimental set up, data collection and analysis are described in Section 2, while results and conclusion are presented in Sections 3 and 4 respectively.

\section{MATERIALS AND METHOD}

A Monocrystalline Photovoltaic module with specifications shown in Table 1 was set up in an outdoor environment to expose it to real life operating conditions at the Quadrangle, Faculty of Technology, University of Ibadan, Oyo State, Nigeria $\left(7^{\circ} 24^{\prime} 7.0632^{\prime \prime} \mathrm{N}, 3^{\circ} 55^{\prime} 2.3268^{\prime}\right.$ 'E). as shown in Figure 1.

The experiments were conducted between October 2017 and January 2018. The solar irradiance $\left(\mathrm{W} / \mathrm{m}^{2}\right)$ incidence on the horizontal surface was measured using solarimeter. The temperature of the module was measured using non-contact infrared digital thermometer and k-type thermocouple temperature data logger. Two different multimeters were used to measure voltage and current respectively.
Table 1: PV Module Specification

\begin{tabular}{ll}
\hline Maximum Power & $150 \mathrm{~W}$ \\
Maximum Power Tolerance & $3 \%$ \\
Open Circuit Voltage & $23.1 \mathrm{~V}$ \\
Short Circuit Current & $8.99 \mathrm{~A}$ \\
Maximum Power Voltage & $18 \mathrm{~V}$ \\
Maximum Power Current & $8.34 \mathrm{~A}$ \\
Weight & $10.2 \mathrm{~kg}$ \\
Dimension (mm) & $1480 \mathrm{by} 670$ by \\
Maximum System Voltage & 30 \\
Maximum Over current & $1000 \mathrm{~V}$ \\
Protection rating & $15 \mathrm{~A}$ \\
Cell technology & Mono-Si \\
Module Application Class & $\mathrm{A}$ \\
\hline
\end{tabular}

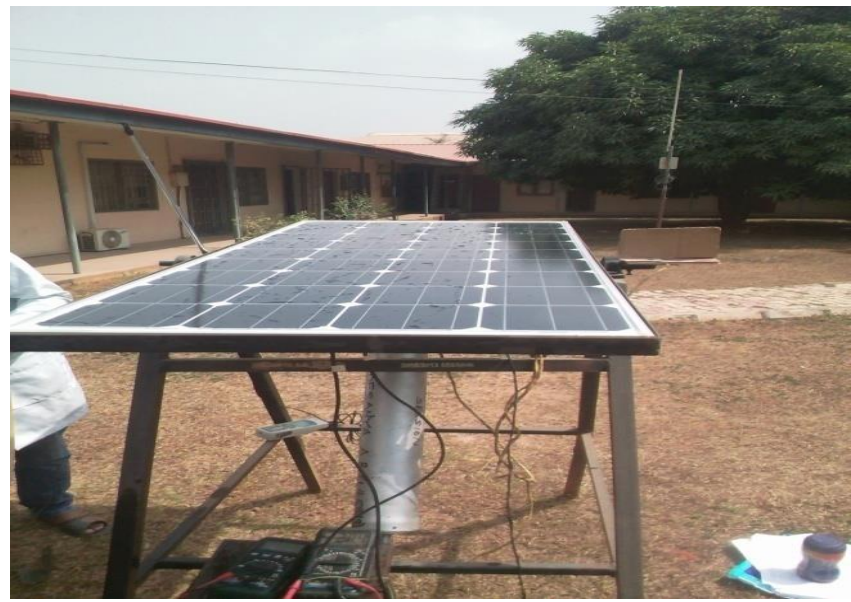

Figure 1: View of the experimental set up without water cooling

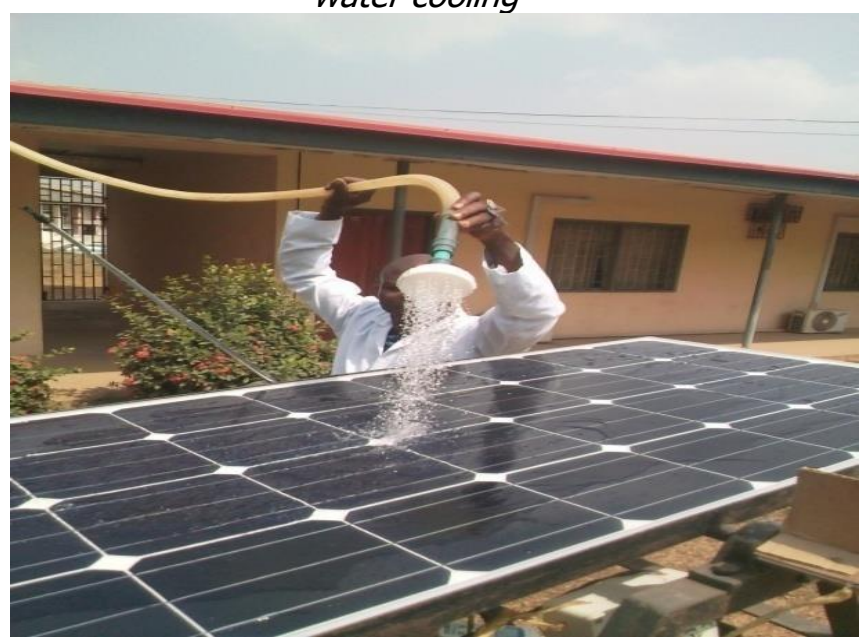

Figure 2: View of the experimental set up with water cooling.

The maximum power delivered by the PV module was calculated from the product of voltage and current recorded. The measurements were taken and recorded every one hour for the period of the experiment from 8:00am - 6:00pm without water cooling. The weather conditions on those days are 
more or less the same. The same procedure was repeated for two days with water cooling using $0.5 \mathrm{hp}$ pump to spray water across the cells for even distribution as shown in Figure 2. All measurements were saved to a Microsoft Excel file for further collation and analysis.

November and December were chosen because it is the hottest period of the year in this region. The cooling process was also repeated every one hour. The time series analysis of the data was done and the result is as shown in the next section.

The photoelectric conversion efficiency was calculated using equation 1 .

$$
\eta=\frac{P_{\max }}{G \times A}
$$

where $\eta$ is the photoelectric conversion efficiency $(\%), G\left(W / m^{2}\right)$ is the solar irradiance incident on the PV module, $A\left(\mathrm{~m}^{2}\right)$ is the surface area of the PV module. $P_{\max }(\mathrm{W})$ is the maximum power generated from the PV module. The maximum power generated is estimated by the product of the voltmeter and ammeter readings.

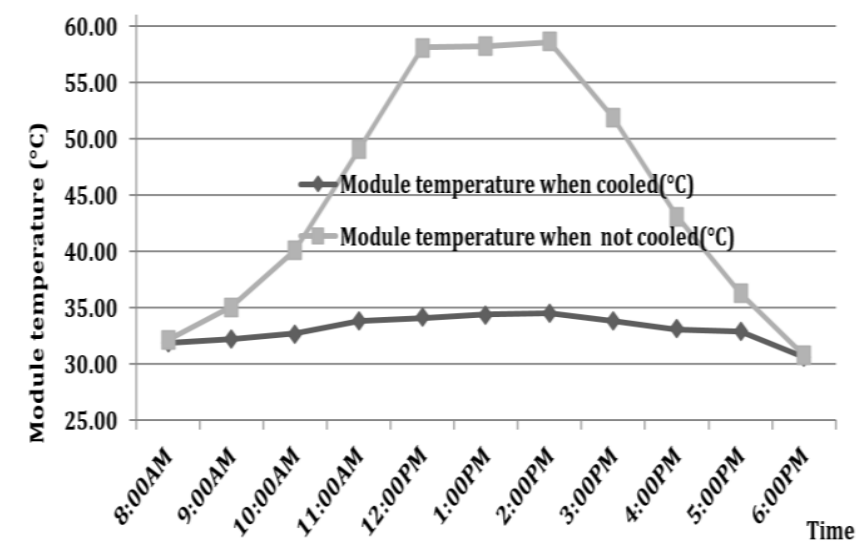

Figure 3: Module temperature when and when not cooled

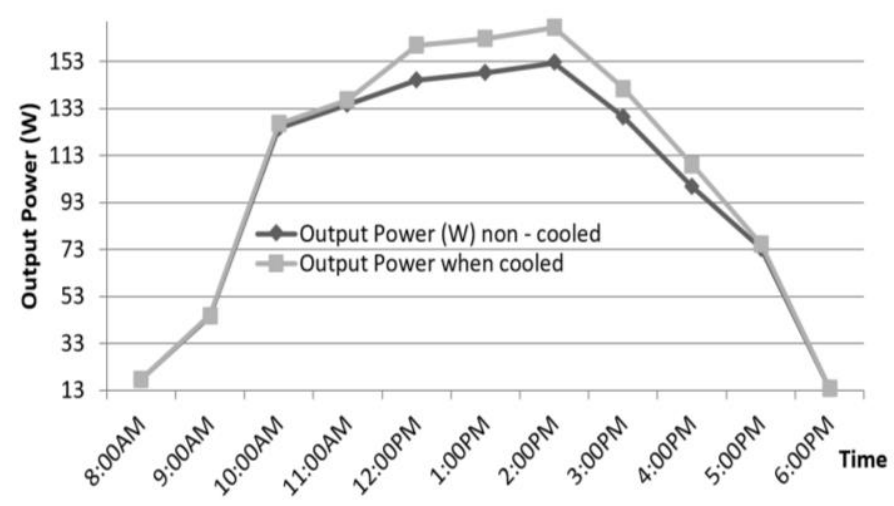

Figure 5: Graph pf output power when cooled and when not cooled

\section{RESULTS AND DISCUSSION}

Analysis of the data collected indicated that increase in temperature of the module leads to a drop in $\left(V_{o c}\right)$ but short circuit current $\left(I_{s c}\right)$ remains significantly unchanged. The module temperature during the experiment begins to increase with increase in solar irradiance. However, when the PV module was cooled, the cooling has no significant effect on the efficiency between 8am - 10:50am but the effect was notable from 11am till 4:30pm as shown in Figure 6. Figure 3 shows the plot of temperature of the module with and without cooling. It was observed that the temperature of the PV module with water cooling decreases maximally by $24.1^{\circ} \mathrm{C}$ and averagely by $11.76^{\circ} \mathrm{C}$.

Figure 4 shows the plot of Open circuit voltage of the module with and without cooling. It was observed that the Open circuit voltage of the module with water cooling increases maximally by $10.06 \%$ and averagely by $5.2 \%$.

Figure 5 shows the plot of Output Power of the module with and without cooling. It was observed that the Output Power of the module with water cooling increases maximally by $9.83 \%$ and averagely by $5.2 \%$.

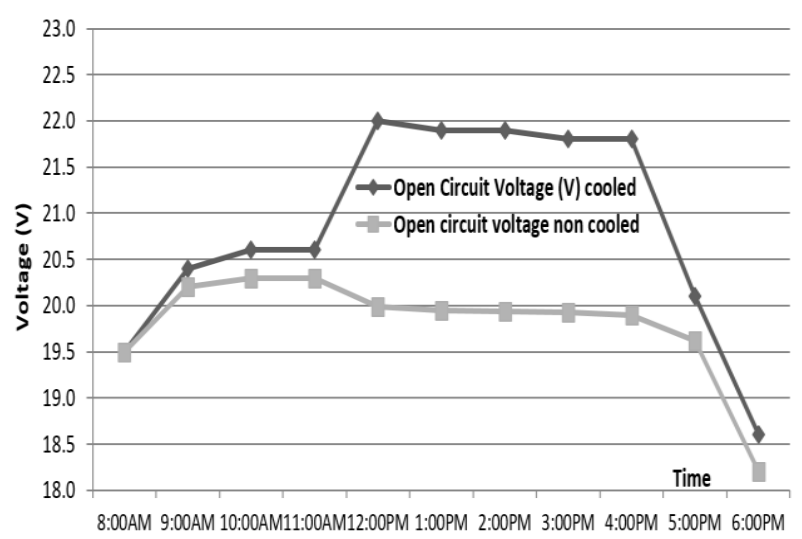

Figure 4: Voltage when cooled and when not cooled

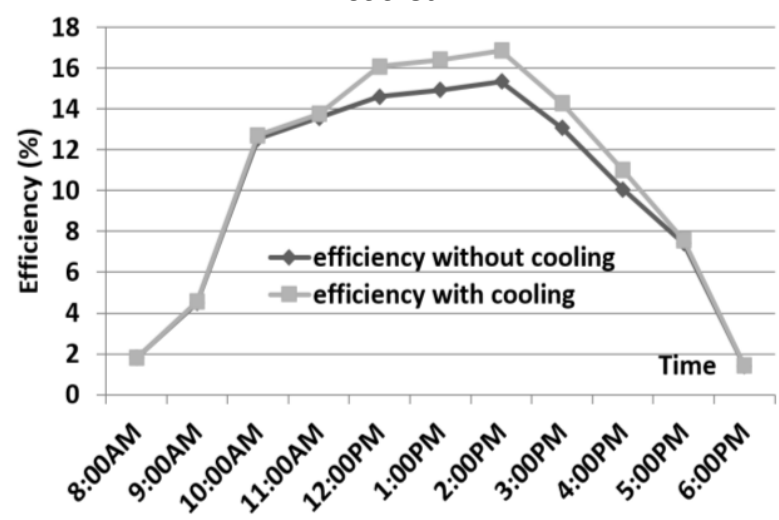

Figure 6: Comparison between PV efficiency when cooled and not cooled

Vol. 38, No. 2, July 2019 
Figure 6 shows comparison on output efficiency per hour of the PV module between cooling and without cooling. From the experimental investigation and results, it was found out that the maximum conversion efficiency of $16.87 \%$ was achieved with water cooling compared to $15.36 \%$ for the noncooled. This indicates a percentage increase of $9.83 \%$.

\section{CONCLUSION}

The effects of cooling on PV module performance in the tropical region have been investigated experimentally. The results indicated that under water cooling condition, the temperature decreased maximally by $24.1^{\circ} \mathrm{C}$. This leads to a percentage increase of $10.06 \%$ of the open circuit voltage, the maximum power delivered by the PV module also increases by $9.83 \%$ and this effectively increases the conversion efficiency of the PV module by $9.83 \%$.

The cooling arrangement maintains the temperature to a certain limit, between $30.6^{\circ} \mathrm{C}$ and $34.5^{\circ} \mathrm{C}$ thereby avoiding long term thermal degradation of the PV module. The result of this work further corroborated the results of works done from other regions [6-9].

From literature reviewed, in temperate region, irradiance value is not as high as that of a tropical region, yet the PV module performs better compared with the tropical region due to low thermal characteristics, therefore in case of large solar farms, cooling mechanisms should be employed to ensure optimal performance.

\section{REFERENCES}

[1] Shahsavar, A.; Salmanzadeh, M.; Ameri, M. and Talebizadeh, P.: "Energy Saving in Buildings by Using the Exhaust and Ventilation Air for Cooling of Photovoltaic Panels." Energy and Buildings, Vol. 43 No.9, 2011, pp 221-226.

[2] Shukla, A.; Khare, M. and Shukla, K. N.: "Experimental Exergetic Performance Evaluation of Solar PV Module" International Journal of Scientific and Research Publications Vol. 5, Issue 1. 2015, pp 1-9.

[3] Amuda, D. B.; Adeleke, D. K. and Orotoye, T. A.: "Experimental Evaluation of the Effect of Temperature of Polycrystalline and Monocrystalline Photovoltaic Module", IOSR Journal of Applied Physics (IOSR-JAP), Vol. 9, Issue 2 Ver. II. 2017, pp $05-10$.
[4] Gardas, B. B. and Tendolkar, M. V.: "Design of a cooling system for Photovoltaic Panel for increasing its electrical efficiency", International Journal of Mechanical and Production Engineering (IJMPE), Vol. 1, 2012, pp 63-67.

[5] Quaschning, V. (2005): "Understanding Renewable Energy System" Earth Scan, USA, 2005 Chapter 4, page 115.

[6] Musthafa, M. M.: "Enhancing Photoelectric Conversion Efficiency of Solar Panel by Water Cooling", Journal of Fundamentals of Renewable Energy and Applications, Vol. 5, Issue. 4, 2015, pp 1-5.

[7] Nikhil, P. G. and Premalatha, M.: "Performance Enhancement of Solar Module by Cooling: An Experimental Investigation", International Journal of Energy and Environment Vol. 3, Issue 1, 2012, pp 73- 82.

[8] Moharram, K. A.; Abd-Elhady, M. S.; Kandil, H. A. and El-Sherif, H.: "Enhancing the Performance of Photovoltaic Panels by Water Cooling "Ain Shams Engineering Journal, Vol. 4, 2013, pp 869-874

[9] Abdulgafar, S. A.; Omar, S. O. and Yousif, K. M.: "Improving the Efficiency of Polycrystalline Solar Panel via Water Immersion Method", International Journal of Innovative Research in Science, Engineering and Technology, Vol. 3, Issue 1, 2014, pp $8127-8132$.

[10] Nnadi, D. B. N.: "Environmental/Climatic Effects on Stand-Alone Solar Energy Supply Performance for Sustainable Energy", Nigerian Journal of Technology (NIJOTECH), Vol. 31, No. 1, 2012, pp 79-88.

[11] Nobre, A.; Montenegro, A.; Zhen, Y.; Reindi, T. and Ruther, R.: "On PV Module Temperature in Tropical Region- a Comparison between System Locations in Singapore and Brazil", IV Congresso Brasiliero de Energia Solar eV Conferencia Latino-Americana de ISES, 2012, pp 1-8.

[12] Omubo-Pepple, V. B.; Tamunobereton-ari, I. and Briggs-Kamara, M. A.: "Influence of Meteorological Parameters on the Efficiency of Photovoltaic Module in Some Cities in the Niger Delta of Nigeria", Journal of Asian Scientific Research, Vol. 3, No. 1, 2013, pp 107-113.

[13] Samadhiya, A. and Pandey, R.: "Analysis of PV Panels under Various Weather Conditions", International Journal of Emerging Research in Management \& Technology, Vol. 5, Issue. 2, 2016, pp 53-61. 
[14] Setiawan, E. A.; Setiawan, A. and Siregar, D.: "Analysis on Solar Panel Performance and PVInverter Configuration for Tropical Region", Journal of Thermal Engineering, Vol. 3, No. 3, 2017, pp 1259-1270.

[15] Nazar, R.: "Improvement of Efficiency of Solar Panel Using Different Methods", International Journal of Electrical and Electronics Engineering, Vol. 7, Issue 1, 2015, pp 12-17.
[16]Amelia, A. R.; Irwan, Y. M.; Leow, W. Z.; Irwanto, M.; Safwati, I. and Zhafarina, M.: "Investigation of Temperature on Photovoltaic (PV) Panel Output Performance", International Journal on Advanced Science Engineering Information Technology Vol. 6, No. 5, 2016, pp 682- 688 . 